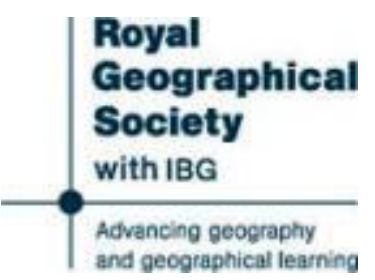

The Distribution of Population in the United States

Author(s): Albert Perry Brigham

Source: The Geographical Journal, Vol. 32, No. 4 (Oct., 1908), pp. 380-389

Published by: The Royal Geographical Society (with the Institute of British Geographers)

Stable URL: http://www.jstor.org/stable/1776928

Accessed: 01-03-2015 01:18 UTC

Your use of the JSTOR archive indicates your acceptance of the Terms \& Conditions of Use, available at http://www.jstor.org/page/info/about/policies/terms.jsp

JSTOR is a not-for-profit service that helps scholars, researchers, and students discover, use, and build upon a wide range of content in a trusted digital archive. We use information technology and tools to increase productivity and facilitate new forms of scholarship. For more information about JSTOR, please contact support@jstor.org.

The Royal Geographical Society (with the Institute of British Geographers) is collaborating with JSTOR to digitize, preserve and extend access to The Geographical Journal. 
proportional to the di ance, and a straight line drawn from any point to the centre represents the direction in which the great circle or line of shortest distance starts. Constructed with London as a centre, for use in England, it seems to correct some common but erroneous impressions. It is seen, for instance, that Jamaica lies nearly due west; that Bombay and Perth, W.A., both lie almost due east, and that the direct and shortest line to Calcutta starts in an east-northeasterly direction; also it shows that when Captain Scott started southwards from the Discovery winter quarters towards the pole he was really making a bee-line for home.

Many other curious results come out from a study of the map, some of them more clearly, and certainly more conveniently, than on a globe, and it seems that a map of this kind, side by side with the Mercator map, would make a more useful combination than any at present procurable.

\section{THE DISTRIBUTION OF POPULATION IN THE UNITED STATES.*}

\section{By Prof. ALBERT PERRY BRIGHAM.}

'l'HE United States had, in 1900, a population of about 76,000,000, an allotment on the average of 25.6 persons to each square mile. In an area not greatly larger Europe had at that date $390,000,030$ people, giving a density of 101 . It is convenient to remember that the density is about four times as great in Europe as in the United States.

Comparing the new country with three of the European peoples, Great Britain, with an area smaller than that of the state of Colorado, had more than $41,000,000$ people, and showed a density of 470, while England exhibited a density of 605 . Belgium, less than one and a half times as large as the small state of Massachusetts, had a density of 616 , ranging from a minimum of 130 in Luxemburg to 1027 in Brabant. The kingdom of Italy is not much larger than the state of Nevada. 'Ihis state had, in 1900 , less than one person per square mile. Italy, in 1901, had 32,000,000 people, and showed an average density of 293 , while the province of Lombardy had 456 persons to each square mile. 'The vast and diversified Dominion of Canada, on the other hand, greater than its southern neighbour, had less than 6,000,000 people, and exhibited a density of about $1 \cdot 75$ to the square mile.

\section{Centre of Population.}

'The centre of population in 1900 was in the state of Indiana. In 1790 the centre was 23 miles east of Baltimore, in the state of Maryland, or virtually on the Atlantic shore-line. Its migration has been slow and remarkably uniform, both in rate and in direction. It has hovered for one hundred and ten years along the 39 th parallel of latitude, and its total variation in latitude has been less than one-third of one degree. The westward movement has averaged less than a degree in a decade, notwithstanding the incredibly swift occupation of a vacant continent by a movement of population westward. The easterly position of the

\footnotetext{
* Read before the Ninth International Geographical Congress, Geneva, July, 1908.
} 
centre of population is in part due to the fact that the eastern part of the continent was first settled, and was settled from the east. The population wave has always been rolling up on the Atlantic lowland, before pushing its crest across the Appalachian highlands. The easterly position of the centre of population is also due to the more evenly distributed and more abundant resources of the eastern half of the United States. It should not be forgotten that the geographical centre of the United States lies some hundreds of miles west of the Mississippi river. The eastern half of the country therefore embraces the Atlantic lowlands, the prairies and Great Lake plains, the Gulf lowlands, and the forests and minerals of the Appalachian mountains and Appalachian plateaux. Over against these are the arid and mountainous areas of the west. Certain areas will be reclaimed to incredible productiveness, and the mineral wealth is vast: but the centre of population may be expected to remain permanently to the eastward of the geographical centre of the land.

\section{Densin'y by Divisions.}

The North Atlantic division of the official census includes the six New Fngland states and the middle states except Delaware. It is essentially the group representing the northern colonies of early days. Here the density is 129.8 . The South Atlantic division ranges from Delaware to Florida, including thus the old southern colonies and Florida. Here the density falls to $38 \cdot 9$, less than one-third as compared with the most sparse district of Belgium. We may compare the North Atlantic and South Atlantic divisions. The northern climate is classed as temperate, with severe winters. The southern climate is temperate to sub-tropical, but not at any point of latitude is it such as to repress population by excessive heat. The northern division has in the main a glacial soil as against a residual soil in the south. The northern division is largely mountain and plateau, with well-matured and fertile valleys, and the south combines with higher mountains equally rich valleys, and superadds a vast extent of coastal plain in a most hospitable climate. In both north and south are ample rainfall and forests. If the physical advantage lies anywhere, the balance would seem to incline to the south.

From the point of view of physiographical relations, the north has a shorter passage from Europe, which may be viewed as important, especially as the more active colonizing and commercial powers of Europe lie in northern latitudes. The north has better harbours than the south, and, perhaps more important than all else, holds the easier passes of the Appalachians.

Historically, early settlements north and south were nearly contemporaneous in Massachusetts and Virginia, as at other points in both regions. But small holdings, free labour, and varied culture obtained in the north, while the plantation, slave labour, and less varied culture, as of cotton and tobacco, ruled in the south. It remains for the economist and the sociologist to measure the force of these influences in retarding the growth of the south. The geographer, however, is safe in concluding that the larger and facile geographical relationships of the north went far to obscure any local advantages of soil and climate of which the south was possessed.

The north-central division includes the five states north of the Ohio river, also Minnesota, Iowa, and Missouri on the west hank of the Mississippi, and the Dakotas, Nebraska, and Kansas farther west. The density in this division is 34.9 . If we omit the four first-named, as extending in part into the arid belt, we shall have a more homogeneous area, and shall find a density of between 50 and 60. If we remember that this is the most fertile great area in the United States, we may observe with surprise that the density is less than half that of the North 
Atlantic division. The explanation is had in the fact that it is much younger and that it is mainly agricultural. It has its great population centres, as Chicago, but it has not yet so fully reached the manufacturing and commercial stage of evolution as has the North Atlantic division, with its innumerable mills, factories, and town centres, and the intensive agriculture that accompanies urban population.

On the other hand, the north-central division has larger density than the much older South Atlantic. This is due to its intimate ancestral relation to the east, to its ample commercial relations with the Atlantic seaboard, to the richness of its soils, and to a more favourable industrial and social system.

The South Central Division includes the States between the Ohio river and the Gulf, and westward to Oklahoma and Texas. Here the density is $23 \cdot 1$. This figure is low, and yet Kentucky, Tennessee and Arkansas are as rich in soil and mineral wealth as the North Atlantic division, while Oklahoma and the Gulf states as a whole are aboundingly favoured in soil, climate, in forests and mineral wealth. The only material exception is the interior of the Texas, where large areas belong to the arid and mountain regions. We must take account here, however, of the repressive influence of slavery, of the comparative inaccessibility of the interior states of this group, and of the remoteness from Europe of the Gulf coast. Aready, however, these repressive conditions are losing their force, through the change of social conditions, the recognition of natural wealth, the improvement of the great waterways of the Mississippi and Ohio, through the extension of railway systems, the building of highways and the general evolution of industry.

The Western division includes the Cordilleran region from the western edge of the great plains in Colorado and Wyoming to the Pacific coast. The density is 3.5, and the explanation of the sparseness is close at hand. It is a region of recent occupation, of vast areas of aridity, of extensive mountain surfaces, and much of it even yet is comparatively inaccessible. It awaits the fuller work of irrigation through private and federal enterprise, the further exploitation of its coal and its precious metals, the regulation of railway traffic and the opening of the Isthmian canal, with increase of commercial life for the great states lying on the Pacific shore line. This enlargement may be expected to follow not only upon easier communication with the east, but in perhaps large measure, may be due to relations with Alaska and the Orient.

\section{Extremes of Density.}

The greatest density exhibited by any state as a whole, is found in Rhode Island, where the figure is 407 . Even in this small state the population is locally concentrated, and a recent writer has shown that but 6 per cent. of the people live west of a north and south line bisecting the state. This western half of the area is more and more given up to the forest.

Massachusetts is next in the scale, having a density of 348.9 ; New Jersey follows with $250 \cdot 3$, and Connecticut is fourth, with 187.5 . These densities in no sense represent the capacity of the soil, but are due to concentration in commercial and manufacturing towns. A large part of Massachusetts is occupied by the mountainous region of the Berkshires, with few people. On the other hand the Connecticut valley and much of the coastal lowland are crowded with towns and with small and intensively cultivated farms. The same is true of the uplands and the Connecticut valley, in the state bearing that name. In New Jersey, we find the density hingeing entirely upon the proximity of two great cities, New York and Philadelphia, lying beyond the bounds of the state. Much of her territory is mountain upland, and sparsely peopled coastal plain.*

* Paper by R. H. Whitbeck, read before the Association of American Geographers, Chicago, 1907. 
The small densities appear in the western division. This region has more than twelve times the area of the United Kingdom, and bears a population less by $1,000,000$ or more than the single city of London. The range is from a fraction of one person, as in Nevada, to about ten, in California. Only one state cast of the Mississippi river fell below a density of ten in the year 1900. This state was Florida.

\section{Rural Density.}

If we omit all centres having a population of 4000 or more, we shall have remaining the agricultural population, and the villages and hamlets whose industries are essentially a part of the rural life. We may here distinguish what we may call the rural density, and thus may gain a rude measure of the extent to which the soil itself is occupied. The total density and the rural density for the several divisions are thrown here in tabular form.

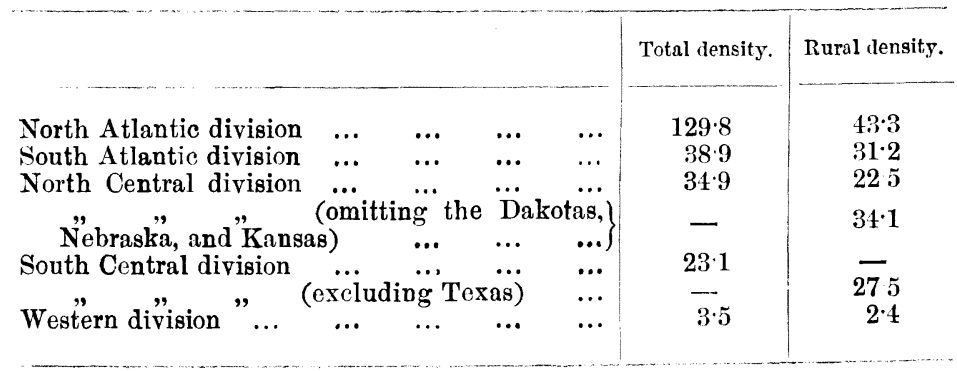

It thus appears that the country east of the arid belt shows rural densities ranging from $27 \cdot 5$ to $43 \cdot 3$. If we now remember that the North Atlantic division has a large number of manufacturing villages with populations falling under 4000 , we see that the rural density is more uniform than the figures indicate. This is yet more clearly shown under the following heading.

\section{Density of Agricultural Workers.}

The United States census for 1900 enables us to exhibit the number of actual agricultural workers for the whole country and its several divisions. The table shows the number for each square mile and the consequent number of acres which receive the labour of one man. The arid belt and all states to the west of it are omitted except in the first item.

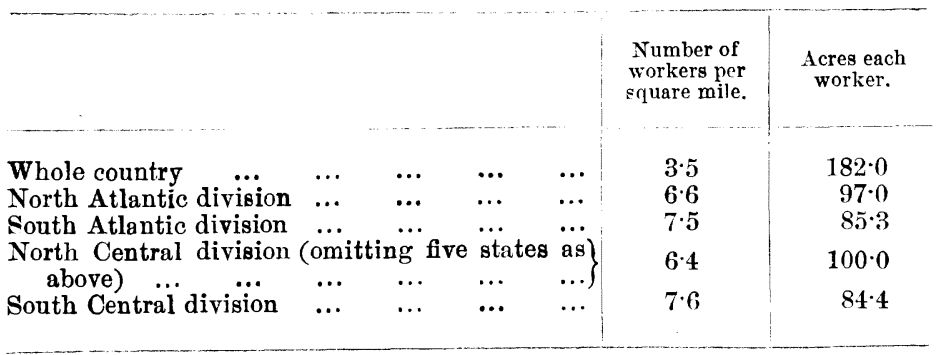

Averaging, it appears that within the region of sufficient rainfall, we find seven agricultural workers for each square mile, or one worker for each 91.4 acres. The 
uniformity, or the approach to this average, of each of the great divisions seems wo"thy of remark. These figures refer not to land in actual tillage, but to the entire land-surface of the several regions.

In each of the divisions except the North Atlantic the acreage under the care of one worker decreased from 1890 to 1900, showing thus a progress toward intensive culture. In the North Atlantic division in that decade the average per man increased from $94 \cdot 4$ to 97 acres. This was no doubt due to the passage of farms or fields into pasture and forest. The real movement in that region, as in the others, is toward intensive farming.

\section{Spectal, Areas of Sturfact and Sort.}

Two examples are taken from the state of New York. The table gives the density and the rural density of four selected counties.

\begin{tabular}{lllll|r|r}
\hline & & & & & Density. & Rural density. \\
Hamilton & $\ldots$ & $\ldots$ & $\ldots$ & $\ldots$ & $2 \cdot 8$ & \\
Chenango & $\ldots$ & $\ldots$ & $\ldots$ & $\ldots$ & $43 \cdot 2$ & $2 \cdot 8$ \\
Delaware & $\ldots$ & $\ldots$ & $\ldots$ & $\ldots$ & $30 \cdot 3$ & $35 \cdot 4$ \\
Orleans & $\ldots$ & $\ldots$ & $\ldots$ & $\ldots$ & $76 \cdot 1$ & $5 \cdot 3$ \\
\hline
\end{tabular}

Hamilton county is wholly mountainous, and nearly all bears forest, being part of the pre-Cambrian Adirondack region. There are no villages worthy of mention, and the two densities are the same. It is a different world from the Palæozoic lands to be found within 50 miles in any direction.

Chenango and Delaware counties belong to the Devonian uplands of the Appalachian plateau, and to that section locally known as the Catskills, and their extension westward. Altitudes of 1500 and 2000 feet prevail, except in the deeper valleys. The chief industry is the dairy, and the towns are small, so that the two densities are equal in Delaware and similar in Chenango.

Orleans county belongs to the lake-plains of the Iroquois region; its surfaces are chiefly level, its soils rich, and its climate ameliorated by the great reservoirs of lake-water. Cereals and fruits rule; the county contains thriving towns, but no cities; and the rural density rises to 53.

The next example relates to surface as well as soil, and has primarily to do with communication. We may well define a transportation belt in New York, namely, the counties lying along the New York Central and Hudson River Railway. This railway passes from the city of New York along the Hudson, westward by the Mohawk pass, and along the lake-plains to the foot of Lake Erie.* Few American routes are so well known in Europe as this. The counties bordering this line of railway contain about 30 per cent. of the land-surface of the state, and they hold 77 per cent. of its population. They contain all the cities rising above a population of 1.00,000, namely, New York, Syracuse, Rochester, and Buffalo. The belt, indeed, includes all the cities surpassing the limit of 50,000, with one possible exception. This is the route also of water communication from the lakes to the sea, and it is in itself peculiarly favoured in its lacustrine and alluvial soils, and in its milder winter climates, as compared with the uplands on either hand.

* “The Eastern Gateway of the United States," A. P. Brigham, Geographical Journal, London, vol. 13 (1899). 
Similar discriminations, on the basis of physical geography, could be indefinitely muliplied by examples from other states, such as North Carolina, Wisconsin, Kentucky, Missouri, or Alabama.

\section{Cities of the First Order.}

The next analy:is will relate to the great cities, and must be in outline, for any adequate treatment would demand a separate paper. We ravk as cities of the first order, all having a population of 250,000 or more in the census of 1900 . There were sixteen such cities. Washington was one of these, but we omit it from further consideration as having been wholly special in its origin and development.

The remaining fifteen fall into tbree groups of five each-marine, lacustrine, and fluvial. The marine cities are Boston, New York, Philadelpbia, Baltimore, and San Francisc?. Two of these are on estuaries and three are on tidal bays, while four are Atlantic ports, and one belongs to the Pacific. In order of population of cities of the first order they stood (1), (3), (5), (6), (8).

The lacustrine cities are Buffalo, Cleveland, Detroit, Chicago, and Milwaukee. Detroit is, indeed, on the short Detroit river, but is no real exception, as it derives its chief importance from its relation to lake traffic. Three of these cities are on or closely related to Lake Erie, and two are on Lake Michigan. There is no great city on the American side of Lake Ontario, the presence of Niagara having forbidden it. And there is no great city on Lake Huron or Lake Superior, although Duluth's importance is not to be measured by its present population. Of Lake Superior it is to be said that it is too far north for domestic trade across the continent, and it is bordered by a rugged region of mineral and forest. The population rank of the lacustrine cities was (2), (7), (8), (13), and (14).

The fluvial cities are Pittsburg, Cincinnati, St. Louis, New Orleans, and Minneapolis-St. Paul. The last is composed of two municipalities, but their situations and their history constitute them essentially a single-river city. New Orleans may be considered as partly marine in its type. Of this group two are on the Ohio river and three on the Miscissippi, all belonging to the Mississippi System.

Of the entire fifteen, only one is west of the 93rd meridian, and but three are west of the Mississippi river, two of these being upon its banks. All but one also are in the Atlantic basin.

If we consider cities between 100,000 and 250,000 , we find them twenty-one in number in 1900. Of these, four may be regarded as dependencies of great cities -Newark, Jersey City, and Paterson as related to New York, and Allegbany as virtually a part of Pittsburg. Of the remaining seventeen, three are tidalProvidence, Fall river, and New Haven; and six are fluvial-Louisville, Kansas City, Omaha, St. Joseph, Memphis, and Rochester. One of these centres, Scranton, is based on the mining of col, three are state capitals, Denver, Indianapolis, and Columbus, and one, Toledo, is lacustrine. Indianapolis would now rank as of the first order, and, like Denver, has important relations other than to the government of its state. The three remaining centres, Syracuse, Worcester, and Los Angeles, are inland towns of various origin.

\section{Concentration of Industries.}

The building of a great industry in a region, or in a specific centre, modifies in important ways the distribution of population. The United States abounds in illustrations of this principle. Such gatherings arise in relation to natural resources, such as combinations of soil and climate. Indian corn may be termed a prairie product, although widely distributed beyond the prairie region. Hot 
summers and wide areas of fertile soil have led to such enormous productions of this crop in Illinois, Iowa, and adjoining lands, that it may fairly be cited as an example of concentration even though other grains are largely grown. The livestock industry follows the corn, though by no means coincident with it, since the natural pastures of the plains reach far beyond the corn belt. The oranges of Florida, or California, the peaches of Niagara, the grapes of Chautauqua, and the fruits and vegetables of the Atlantic coastal plain offer further examples.

The Cordilleran States abound in groups of population centred around a single industry, usually agriculture or mining, and the one is as striking and conspicuous as the other. If the rush of people for gold in California was spectacular and dramatic fifty years ago, the concentrations due to fruit and grains are scarcely of less absorbing interest in the central valley of the San-Joaquin and the Sacramento at the present time. The Willamette valley in Oregon, the plantations of Utah, and the farms about Greeley, in Colorado, afford noble examples of agricultural concentration in a region where deposits of silver and gold are more commonly remembered as explaining the origin of population groups.

Concentration due to mineral resources is well typified by Pittsburg, where, however, facilities for transportation and relation to other important centres must not be forgotten; or we may turn to the Southern Appalachian valley, where coal and iron are the dominant factors, supplemented by agricultural conditions of a high order.

Resources in the form of power have played a most important part, and perhaps our most available illustration is southern New England, where the streams and waterfalls were obviously and instantly available in a time when coal had not been exploited, and when there were no transportation facilities worthy of the name. Water-pcwer determined the industry and the dense populations of that region, even though fuel power now plays so large a part, and other interests enter in to baffle analysis.

Resources of mine and soil must always combine with favourable transportation. Pittsburg has been cited, and Cleveland, Buffalo, and New York, among others, might be studied with the utmost profit in this connection. The products may be of remote origin, as are the iron and the grain in relation to Buffalo, but the concentration is sure, if the site is in the track of inevitable movement, as determined by grades, navigable waters, and by the position of other growing groups of population.

When a great centre has been established in response to such conditions of environment, then the needs of the population enter as a further factor to react on environment, and give colour and character to all surrounding life. Thus the agriculture of New York and New England has been modified, not only by competition from without, but even more profoundly by the needs of New York and Boston. The single requirement of dairy supplies for these cities largely controls the agriculture for a radius of 300 miles. The growth of these cities, the perishable character of the product, and the imperative needs of millions of people, have almost revolutionized the farming of these regions within a single generation.

The distribution of resources of raw material, of power, and transportation routes is fundamental, but the historical order in which they are found and brought to use is also important, because interests once established are conservative, and tend to hold their place. This inertia will be effective until the tendency to a more natural balance becomes overwhelming. Under such impulse we are brought to the- 


\section{Migration of Industries.}

The migration of industries, in the course of more perfect adjustment to nature, may or may not involve the movement of the populations engaged. As the centre of wheat and other grains receded from Western New York to Ohio, to Illinois, to the trans-Mississippi prairies and plains, the movement involved a vast transfer of population, because a new country was exploited, and the same movement is now going on toward that possible vaster wheat centre of coming years in the plains of Canada.

Another migration is in progress, viz. that of cotton manufacture, which appears to mean a shifting of occupation rather than of people. So far as New England may be forced to retire from this field she will turn to other toil the hands of her people. So far as the south may avail to carry her own product from the gin to the lcom, she will do so by training her own people to new skill. That labour is mobile is indeed shown by the existence of the large French Canadian mill population of New England, but there seems no reason to predict that any considerable body of New England people will, under an industrial impulse, seek the south.

\section{Capacity of the United States for Population.}

The data thus reviewed serve to raise this interesting question, although failing to afford foundation for more than general conclusions. In the long run, the number of people which a land can support depends, not only on the kind and amount of soil, but upon all other resources, and upon the economic condition of all the countries with which relations are maintained. The sources of error in such computations are numerous and grave.

It has been estimated that the Mississippi valley could support 250,000,000 as well as it now supports $41,000,000$ people.* Smaller farms, more effectively utilized, would be needed. Prof. A. B. Hart, writing of the future of the Mississippi valley, compares this region with the valleys of the Hoangho and Yang-tse-king, and concludes that the American valley could comfortably maintain $350,000,000$ people. There seems room, however, to compare carefully the standards of "comfort" obtaining on the plains of China in the past, and those standards which will prevail in the fertile heart of the United States in future ages. It cannot be a matter of interest for the geographer or the historian to know how many human beings can maintain a bare existence within a given territory. Further comparisons, however, seem to justify Prof. Hart's estimate, and certainly bear out Mr. Justin Winsor's figure of 200,000,000. The Hart estimate gives a density of 282 . Remembering that Belgium has 616 , we are requiring but 46 per cent. of the resources needed for the present scale of living in Belgium, a country in which the standard of comfort would seem to be reasonably high. We make due allowance also for the waste, arid lands of the Mississippi valley. In forest and mineral riches our valley seems equal to Belgium, and the future will bring its transportation facilities to comparable completeness. We may accept freely the view that the forests of Kentucky, Tennessee, and Georgia are capable of supporting a population as the Black Forest or the Jura.

The island of Java has recently been taken as an example of large capacity for population. $\dagger$ With an area slightly above 50,000 square miles, the island had in

* Mr. F. A. Ogg, 'World's Work,' vol. 12, October, 1906.

$\dagger$ A. Weikoff, ‘Annales de Geographie,' vol. 10, 1901. 
1896 a population above $26,000,000$, and a density of 518 . The island raises its own food, and the writer thinks that $106,000,000$ people could here live with ease, and with suitable variety of food. This means a density of 2000 . The author works towards the general conclusion that the equatorial belt of $30^{\circ}$ in width could safely support $10,000,000,000$ people, or seven times the present number of our race. We here again raise the query, whether, if rice enough for subsistence could be grown, other things having exchange value could be produced to provide for the comforts and general advantages of civilized life. And before adopting Java as a criterion for the Mississippi valley, we must observe that rice grows in but a small part of the valley, and that the future people of that region can hardly be expected to make rice their staple food. It would remain, therefore, for the careful student to compare the quantity and nutritive value of the various cereals with those of rice. We should further take into account the annual successions of crops possible to a luxuriant tropical region.

\section{ILLINOIS.}

As a limited area, and therefore capable of more exact comparison, we may take this great prairie state. It has a land area of 56,000 square miles. Its population in 1900 was nearly 5,000,000, and its density was 86. Again we compare with Belgium, which has an area less than one-fifth as great, a population greater by nearly $2,000,000$, and a density sevenfold greater. The density of Belgium would give Illinois nearly $35,000,0 \mathrm{CO}$ people. The density of Java would give the prairie state $29,000,000$, the area not being greatly different. England is * not quite as large as Illinois, and has over 30,000,000 people. The density of England would give Illinois nearly 34,000,000.

There is almost no waste land in the state, and the soil is of high quality. It is probable that in food capacity in proportion to its area Illinois surpasses any of the above examples from the older continents. In other resources she excels in coal, nearly two-thirds of her surface being underlaid by beds of this fuel. She can raise timber if she can spare the land, but is deficient in most metallic minerals. She is prospectively as favoured as any land in commercial and transportation facilities, focussing the trade of the transcontinental railways and of the Great Lakes, and to be open soon to the full possibilities of Mississippi and Isthmian navigation. We may thus conclude that this single state can and will enormously increase its population. But it is not safe to prophesy in figures.

\section{The United States and its Future Population.}

If we exclude the arid and mountinous regions of the West, what remains would appear to have as great an average capacity for population as England. If we take the point of view of soil and topography, it would seem that the poor areas of our Appalachian uplands were amply offset by the meadows and thin pastures of the Pennine range, of the English lakes, and of Devon and Cornwall. England has reclaimed her fens, and we have the probable estimate that as much good land can be reclaimed by drainage east of the Mississippi river as by irrigation to the west of it. As regards abundance of general resources for export, the United States are more favoured than England in coal, iron, petroleum, and copper, while her climatic range puts into her hands maize, tobacco, rice, sugar-cane, cotton, and all sub-tropical fruits.

Let us see our results, on the basis of equality with England, in the population capacity of the eastern United States. We omit the Western division, Texas, Kansas, Nebraska, South Dakota, and North Dakota. It is perhaps surprising 
that but little more than two-fifths of our territory remains, although including a full tier of States west of the Mississippi river. With a density equal to that of England, this eastern part would contain 742,000,000 people. It remains for our posterity to see how far these theoretical possibilities become real.

\section{Summary Analysis of Factors-controlling Distribution.}

The present discussion has given sufficient evidence that these factors are many in number, complex in action and difficult of analysis. They are at the same time interesting, because of the wide range and sharp contrasts in the physical conditions, and because of the brief history and swift changes of the United States.

We enumerate $(a)$ soil, rainfall, and temperature, which issue is what we may call crop-capacity. Thus, even if no other factor operated, Belgium must, by virtue of these conditions, always have a much greater population than Norway. Massachusetts, as we have seen, has a density of 349 , while Illinois, far richer in the produce of the soil, shows but 86 . This means that other factors have wrought and still are powerful. A second factor, or group of factors, is $(b)$ the mineral, forest, and power resources, leading to concentration of industries and to corresponding massing of population. A simple case is found in the large towns and cities of the region of anthracite coal in Pennsylvania. The coal lies in a rugged tract which, but for this mineral, must ever have been sparsely peopled. Other examples have been given in the brief account of conditions of concentrations. We name $(c)$ physiographical relations. This factor, as we have seen, goes far to explain the dense populations of the North Atlantic, as compared with South Atlantic states. It is further illustrated by the transportation belt in New York, and by the growth of such centres as Chicago and Denver. Finally, $(d)$ historical and social conditions must never be neglected. However reluctant the geographer may be to step beyond his own sphere, he must reckon with the character of races and the march of events through the centuries. Indeed, we may be assured that the c smplex adjustment of the human race to our planet will be truly interpreted for the geographer, when the problem has long been studied from the points of view of geography, history, ethnology, political economy, and social science. It would be rash to conclude that the above, or any proposed catalogue of factors influencing distribution, is complete.

In conclusion, the following general deductions seem, to the writer, important and appropriate :-

(1) The distribution of population, casually studied, offers to geographers an important field of research.

(2) The distribution of popalation, so studied, should have a large place in geographical and historical education.

(3) Such study promotes the scientific organization of geography, because it unfolds a process of progressive adjustment to environment.

(4) A young country, such as the United States, offers opportunity for such investigation, because of its physical variety, its brief history, and the resulting facility with which its changes can be seen and interpreted. 